\title{
Diversity and distribution of immature vectors of malaria and rift valley fever in habitats along an altitudinal gradient in Barigo, Kenya
}

\author{
KOBIA DANCAN, GEORGE O. ONG'AMO", PAUL NDEGWA \\ School of Biological Sciences, University of Nairobi. Nairobi, Kenya. "email: gongamo@uonbi.ac.ke \\ Manuscript received: 7 January 2018. Revision accepted: 5 June 2018.
}

\begin{abstract}
Dancan K, Ong'amo GO, Ndegwa P. 2018. Diversity and distribution of immature vectors of malaria and rift valley fever in habitats along an altitudinal gradient in Baringo County, Kenya. Bonorowo Wetlands 8: 25-32. Malaria and RVF are two diseases whose onset of epidemics leads to massive losses in human lives. Infected Anopheles mosquitoes transmit Plasmodium parasites that cause malaria, while infected floodwater Aedes species are responsible for the primary transmission of RVF viruses. The high mobility of adult mosquito species has rendered interventions targeting their behavior ineffective. Thus, interventions that target immature stages an advantageous. For effective implementation of immature stage-based control strategies, information on their diversity and distribution in various habitats distributed along altitudinal gradients is important. This study investigated the diversity and distribution of malaria and RVF mosquito vectors at immature stages along an altitudinal gradient in Baringo County, Kenya, during the short rains season. The species identified in the entire study area $(800 \mathrm{~m}$ to $2300 \mathrm{~m}$ above sea level) were Culex quinquefaciatus, Cx. annulioris, Cx. pipiens, Cx. poicilipes, Cx. tigripes, Anopheles pharoensis, An. gambiae s.l, An. coustani, An. funestus, and Aedes taylori. Altitude was divided into three classes; $800 \mathrm{~m}$ to $1300 \mathrm{~m}, 1301 \mathrm{~m}$ to $1800 \mathrm{~m}$, and $1801 \mathrm{~m}$ to $2300 \mathrm{~m}$. Aedes taylori and Cx. tigripes were only in the $1801 \mathrm{~m}$ to $2300 \mathrm{~m}$ altitudinal class while An. funestus was only in the $800 \mathrm{~m}$ to $1300 \mathrm{~m}$ altitudinal class. The altitudinal class between $1801 \mathrm{~m}$ to $2300 \mathrm{~m}$ had the lowest Shannon-wiener diversity index $\left(\mathrm{H}^{\prime}=0.9836\right)$ of species $(9$ species $)$. Comparison of mosquitoes collected in habitats in different altitudinal classes revealed variations in the respective species counts $\left(\chi_{2}^{2}=127.47 ; \mathrm{p}\right.$-value $<0.001)$. The only species whose distribution showed correlation with altitude was An. pharoensis $(\mathrm{r}=-0.40 ; \mathrm{t} 32=-2.50 ; \mathrm{p}=0.02)$. The highest species diversity was recorded in riverbanks, where the water was clear and vegetation was present. Stepwise regression analysis revealed that the suitability of a habitat for vector breeding was mainly dictated by water quality and the presence of vegetation. The results in this study reveal the need for continuous monitoring of vectors in the low land areas and the highland areas to avoid sudden epidemics of malaria and RVF.
\end{abstract}

Keywords: Aedes, altitudinal gradient, Anopheles, Culex, diversity, immature vectors

\section{INTRODUCTION}

Malaria and Rift Valley Fever are vector-transmitted diseases that have claimed many lives in tropical Africa (Woods et al. 2002; WHO 2013b). Malaria is caused by protozoan parasites of the genus Plasmodium transmitted by infected female mosquitoes of Anopheles. It is currently the leading cause of mortality and morbidity in many countries, with $90 \%$ of the mortalities in Africa (WHO 2013a). In Kenya, $20 \%$ of reported child mortalities under 5 years result from malaria (KEMRI 2014). Baringo County in Kenya is one of the malaria-endemic zones and experiences seasonal epidemics.

Rift valley fever, the second vector transmitted a Phlebovirus of the family Bunyaviridae, causes disease. Trans-ovarian transmission maintains rift valley fever in floodwater Aedes mosquitoes. Outbreaks are associated with heavy, prolonged rainfall, which is often related to the El Niño phenomena. Secondary transmission in epidemics is mainly by female Culex mosquitoes and biting flies (Swanepoel et al., 2011; El Vilaly et al., 2013). From 2006 to 2007 Kenyan epidemic, 684 cases were reported, including 155 human deaths (23\%). Among the 684 cases, about 183 were in the rift valley (WHO 2007), part of Baringo district (now Baringo County).
Like other insect species, the distribution range of many insect disease-vectors, including the Anopheles, Culex, and Aedes species, is defined by climatic factors that favor their respective physiological functions (Githeko et al. 2000). Factors such as temperature, humidity, and precipitation vary along the altitudinal gradient ( $\mathrm{Li}$ et al., 2012). Altitude, therefore, indirectly defines the occurrence and distribution of insect vector species in many regions and sometimes creates buffer zones for vector-borne diseases (WHO 1975; Cox 1999). The altitudinal ranges of these climatic factors are changing with the general global climate change. These changes are likely to affect vector distribution ranges (Wettstein and Schmid 1999; Kiratani 2006). Therefore, it is essential to continuously monitor changes in the diversity and distribution of these vectors to prevent outbreaks of vector-borne diseases (Wettstein and Schmid 1999; Kiratani 2006). Such information can be used to determine epidemic thresholds for vector management (Bacaer and Guernaoui 2006).

The objective of this research was: (i) To determine the diversity and distribution of malaria and RVF mosquito vector species larvae along the altitudinal gradient. (ii) To evaluate habitat suitability for Malaria and Rift Valley fever vector breeding based on water quality, vegetation, and presence of other organisms in a habitat. 


\section{MATERIAL AND METHODS}

\section{Description of the study area}

The study area is approximately $252 \mathrm{~km}$, North West of Nairobi, Kenya, measuring about $3,500 \mathrm{~km}^{2}$. It lies in an agro-pastoral zone within Baringo County, Kenya. The temperature range is between $24^{\circ}$ in the cold season and $30^{\circ}$ degrees in the warm season. The average annual rainfall in the highland is between $1000 \mathrm{~m}$ and $1500 \mathrm{~m}$, while the low lands experience a yearly rainfall of about $600 \mathrm{~mm}$. It is located between $35.602 \mathrm{E}, 0.541 \mathrm{~N}$, and $36.277 \mathrm{E}, 0.723 \mathrm{~N}$, with elevation ranging from $800 \mathrm{~m}$ to $2300 \mathrm{~m}$ (Figure 1). This area is characterized by the presence of lakes and rivers, some of which are seasonal.

\section{Sampling points}

Sixteen sampling points were established in the study area with the help of officers from Marigat DVBDU and the google earth android application. The scores were selected based on the availability of potential larval habitats and accessibility. A handheld GPS receiver recorded each point's coordinates and elevation (Garmin, model $e$-Trex $10)$.

Elevations were divided into three classes for analysis, based on the land cover as viewed on an Arc map 3.0 imagery base map (Figure 1). They included $800 \mathrm{~m}$ to1300 $\mathrm{m}$ to represent low altitude gradient, $1301 \mathrm{~m}$ to $1800 \mathrm{~m}$ for mid-altitude, and $1801 \mathrm{~m}$ to $2300 \mathrm{~m}$ for high altitude. The class range was obtained by subtracting the lowest $(800 \mathrm{~m})$ from the highest point $(2300 \mathrm{~m})$ in the study area. The difference was then divided by three. One was added to the lower limit of each class except for the first range to avoid points falling into two categories.

The sampling points were grouped into the three altitudinal classes. The Low altitude points were, Kapkuikui, Loboi, Lake 94, Nteppes, Salabani, and Kambi ya Samaki. The Middle altitude points included: Kipcherere, Kimau, Yomu, Sabor, Kabeswa, and Sabor. At the same time, the high altitudinal points included: Kurget, Talai, Kaplewa, Kaptimbor, Borowonin, Tandui, Sacho, Kamonol, and Sacho.

\section{Habitat census}

Potential habitats were identified within a $50 \mathrm{~m}$ radius from the sampling point. The $50 \mathrm{~m}$ range was arrived at while considering individuals undertaking the sampling exercise on foot and the minimum distance recorded in adult mosquito flight experiments (Tsuda et al. 2008; Verdonschot and Besse-Lototskaya 2014). An area was identified as a potential habitat if there was water with little to no flow (stagnant). This was because mosquitoes prefer shallow water with minimum flow/stagnant water (Norris 2004).

The habitats were classified according to their nature, based on a combination of factors. There were habitat forms such as a hoof print, swamp, water pan, dam, stream margins, spring margins, pit, lake, flood zone and marsh (Figure 2), presence or absence of vegetation, presence or absence of any other aquatic organisms apart from immature mosquitoes and water quality which was qualitatively classified as definite or turbid. The various combinations of these factors were observed and recorded during the collection of immature mosquitoes. Turbidity was estimated by dipping and collecting water with a transparent $100 \mathrm{ml}$ container in the habitat from down-up. The collected water was allowed to settle for 2 minutes in the bottle before checking the visibility of a three-inch white tile placed under the container. If the tile was visible, the habitat was classified as clear, and if it was not visible, it was classified as turbid. The observation was done directly in the habitat in habitats too shallow for using the $100 \mathrm{~mL}$ container.

\section{A sampling of mosquito larvae from aquatic habitats}

Every two weeks, sampling for immature mosquitoes was carried out between $6^{\text {th }}$ June 2014 and $28^{\text {th }}$ August 2014. The sampling period coincided with the rainy season, and a total of five sampling sessions were completed in all selected aquatic habitats.

During sampling, immature mosquitoes were collected using $350 \mathrm{ml}$ WHO standard dippers at a maximum of 30 dips per habitat (Figure 3). The plastic pipette was used in extremely shallow habitats. The sampler ensured that his shadow was cast away from the habitat. This method could minimize the chances of immature mosquitoes swimming to the bottom of the habitat. The dipper was lowered gently at an angle of $45^{\circ}$ so that collection was done by displacement suction. This way, there was minimal water disturbance, increasing the probability of capturing more immature mosquitoes. Where there was dense vegetation, water was disturbed so that larvae and pupae moved downwards. Vegetation was then cleared using the dipper. A waiting period of 3 to 4 minutes would ensue before collecting the immature mosquitoes. In clumps of vegetation such as grass, the dipper was pressed gently into the plant so that water flowed in.

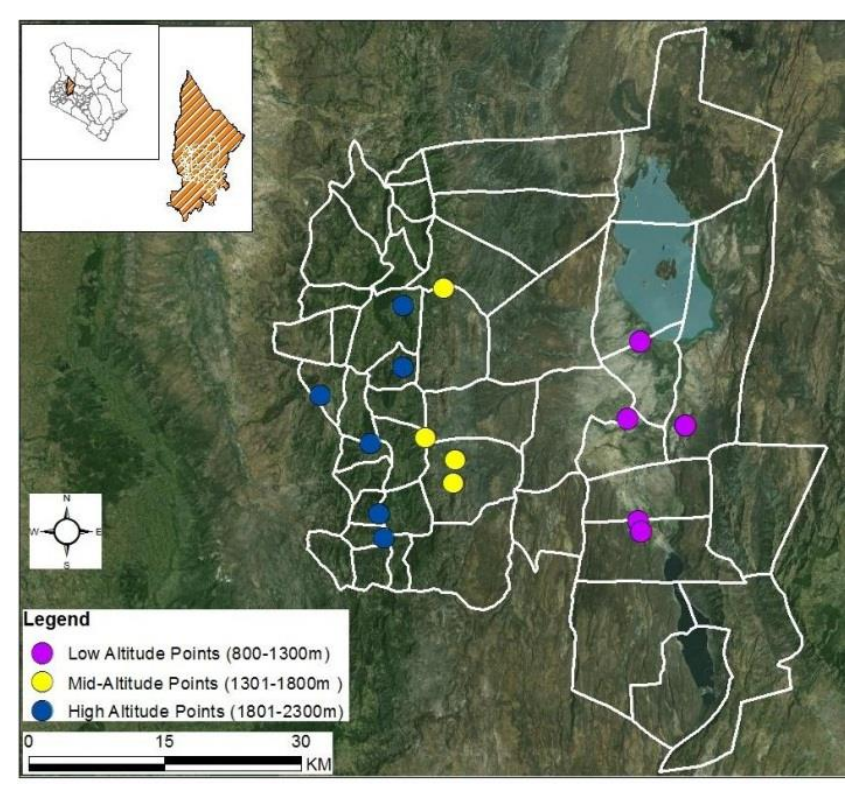

Figure 1. Map of Baringo County, Kenya, showing the study area and sampling points grouped into the three altitudinal classes. 


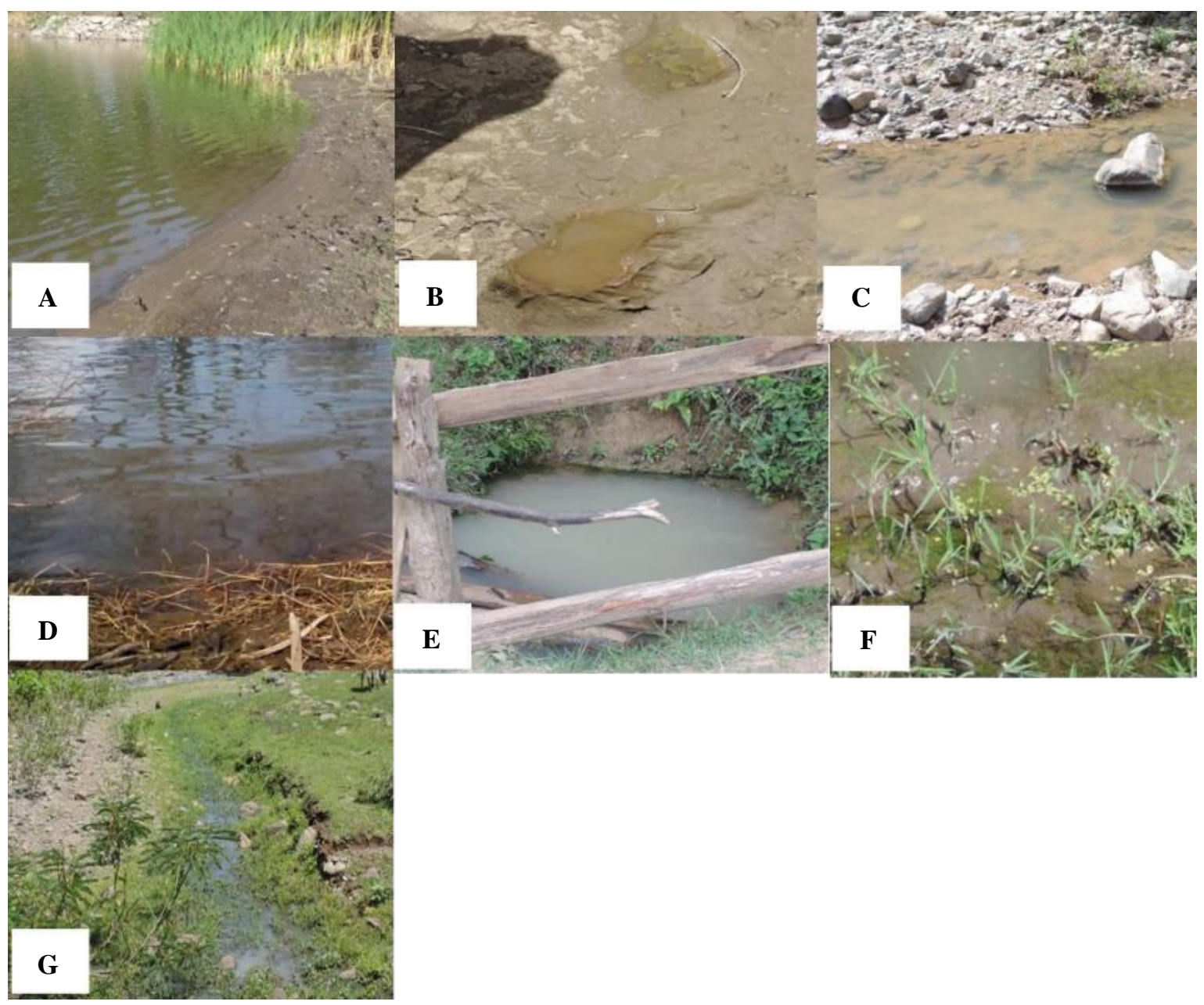

Figure 2. Images of different aquatic habitats: dam margin (A); animal hoof print (B); stream bank (C); Lake Flood zone (D); water pit (E); mash (F); spring bank (G)

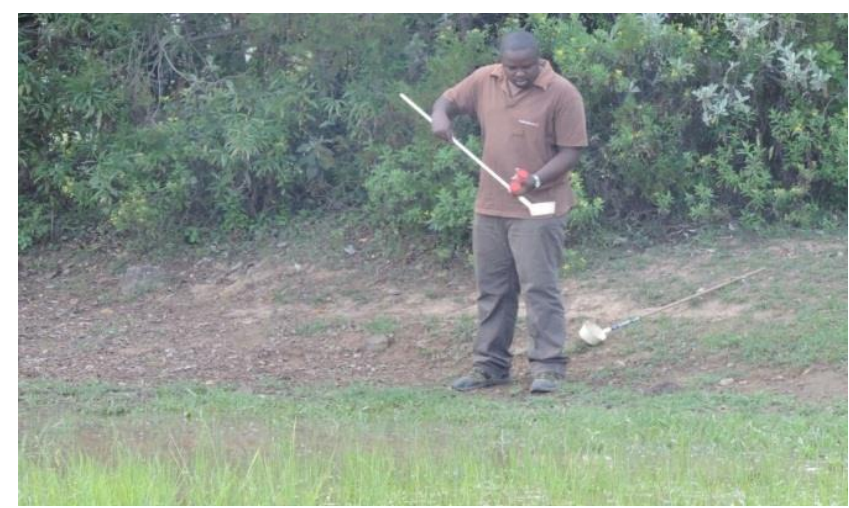

Figure 3. The researcher was inspecting the dipper for immature mosquitoes

After collection, the immature mosquitoes were transferred into a sealable collection cup using a plastic pipette, directly from the habitat onto a pipette, and finally into the sealable container. The collection cups were filled with water sourced from respective sampled habitats to avoid desiccation of the specimen. A pencil written label

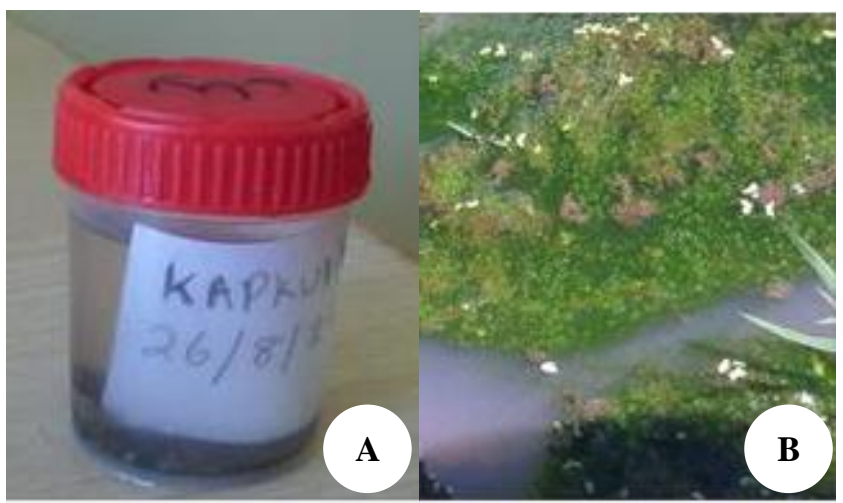

Figure 4. The collection cup contained immature mosquitoes (A), Algae in a habitat (B)

indicates the point and date of the collections immersed into the cup before sealing and subsequent transportation to the DVBDU laboratory in Marigat.

In the laboratory, third and fourth instar larvae were identified (while still alive on a petri dish, using a dissecting microscope) and separated from second and first 
instar larvae. The third and fourth instar larvae were stored in labeled, sealable cups containing $80 \%$ ethanol, waiting for identification to species level.

The first and second instar larvae were put in labeled cups, three-quarters full of water from the source habitat containing algae, and loosely sealed to allow air in and out (Figure 4). To develop the fourth instar, they were left at room temperature (an average of $29^{\circ} \mathrm{C}$ during the day) to develop the fourth instar. Each cup contained not more than 12 larvae. A week before the first collection, an experiment showed reduced development in instances where there were more than 12 larvae in a cup. It was also observed that development from second to fourth instar, at room temperature, took a minimum of one and a maximum of two days in a cup containing water and algae from the source habitat compared to four days when tap water was used.

\section{Identification of larvae}

Ethanol-preserved larvae were identified to species level using third and fourth instar morphological keys under guidance from experts in the Marigat DVBDU (Mark Rotich and Richard Borr). This was by observing features such as the color of the head, arrangement and shape of abdominal setae, number and type of combs, distinct hairs on the sandal, siphon index, and other markings and features on the body surface as guided by the identification key (Gillies and de Meillon 1968). This was done under a dissecting microscope.

\section{Data analysis}

Species diversity analysis was performed on PAST version $2.17 \mathrm{c}$. Other statistical studies were conducted on $\mathrm{R}$ version 3.1.1. To standardize the abundance of a species collected in each habitat, the total number of individuals organized for that species was divided by the average number of dips in the habitat and the quotient multiplied by 30. Thirty (30) was the maximum number of dips for all habitats. Standardization ensured that figures were comparable among all habitats. The chi-square test made a comparison of mosquitoes collected in different altitudinal classes. A generalized linear model (GLM) was used to estimate the effect of various habitat parameters on diversity and the abundance of species. Linear correlation analysis was applied to evaluate the association between altitude and the variety and distribution of species in the study area.

\section{RESULTS AND DISCUSSION}

\section{Diversity along the altitudinal gradient}

A total of 1,536 immature mosquitoes were collected, from which 10 mosquito species were identified. Concerning distribution along altitudinal gradients, 8 species (Cx pipiens, Cx. quinquefaciatus, Cx. annulioris, Cx. poicilipes, An. pharoensis, An. coustani. An. Gambiae, and An. funestus) were found in the altitudinal class range varying between $800 \mathrm{~m}$ and $1300 \mathrm{~m}\left(\mathrm{H}^{\prime}=1.462\right)$, with 7 (Cx pipiens, Cx. quinquefaciatus, Cx. annulioris, $C x$. poicilipes, An. pharoensis, An. coustani. and An. gambiae) found between $1301 \mathrm{~m}$ and $1800 \mathrm{~m}\left(\mathrm{H}^{\prime}=1.686\right)$ and 9 species (Cx pipiens, Cx. quinquefaciatus, Cx. annulioris, Cx. poicilipes, An. pharoensis, Cx. tigripes, An. coustani, An. gambiae and Ae taylori) between $1801 \mathrm{~m}$ and $2300 \mathrm{~m}$ $\left(\mathrm{H}^{\prime}=0.9836\right)$. Ofall the identified species, only seven $(C x$ pipiens, Cx. quinquefaciatus, $C x$. annulioris, $C x$. poicilipes, An. pharoensis, An. Coustani, and An. gambiae) were common in the three altitudinal zones, with An. funestus limited to lower altitudinal zone while both $C x$. tigripes and Ae. taylori were found in higher altitudinal zones $(1801 \mathrm{~m}-$ $2300 \mathrm{~m})$ only. The Buza and Gibson evenness $\left(\mathrm{e}^{\wedge} \mathrm{H}^{\prime} / \mathrm{S}\right)$ showed that the $1301 \mathrm{~m}$ to $1800 \mathrm{~m}$ altitudinal class had higher regularity $(0.77)$, followed by $800 \mathrm{~m}$ to $1300 \mathrm{~m}$ altitudinal level (0.53), and $1801 \mathrm{~m}$ to $2300 \mathrm{~m}$ altitudinal class (0.3) (Table 1).

Comparison of mosquitoes collected in different altitudinal classes revealed variations in the respective species counts $\left(\chi_{2}^{2}=127.47 ; p\right.$-value $\left.<0.001\right)$. There was, however, no variation in the total number collected among the different altitudinal classes $\left(\chi_{2}^{2}=2.17 ; p\right.$-value $\left.=0.34\right)$. Of the 1,536 immature mosquitoes collected, $C x$. quinquefaciatus constituted $58.8 \%$, dominating the species community, while An. funestus made only $0.04 \%$ of the total collection.

\section{Distribution of mosquito species in the altitudinal ranges}

The distribution of various species along the altitudinal ranges was varied (Table 1). However, most of the species showed no correlation with altitude, as described below.

\section{Culex species}

Four Culex species were identified in both $800 \mathrm{~m}$ to $1300 \mathrm{~m}$ and $1301 \mathrm{~m}$ to $1800 \mathrm{~m}$ altitudinal ranges, with five Culex species identified in the $1801 \mathrm{~m}$ to $2300 \mathrm{~m}$ altitudinal range (Table 1). Culex species identified in $800 \mathrm{~m}$ to 1300 $\mathrm{m}$ included $C x$. quinquefaciatus (886.6), $C x$. pipiens (206.3), Cx. annulioris (76.0) and Cx. poicilipes (18.8), while $C x$. quinquefaciatus (409.0), Cx. poicilipes (126.3), $C x$. pipiens (91.9) and Cx. annulioris (126.5) were identified in $1301 \mathrm{~m}$ to $1800 \mathrm{~m}$ altitudinal range. The five Culex species identified in $1801 \mathrm{~m}$ to $2300 \mathrm{~m}$ intervals included Cx. quinquefaciatus (1684.2), Cx. pipiens (175.0), $C x$. annulioris (130.0), Cx. poicilipes (105.9) and $C x$. tigripes (24.9).

Culex quinquefaciatus was the most abundant mosquito species in the entire study area and Culex species in the three altitudinal class ranges. Culex poicilipes was the least abundant in the class range between $800 \mathrm{~m}$ to $1300 \mathrm{~m}$ while $C x$. annulioris and $C x$. pipiens were the least abundant in the altitudinal class range between $1301 \mathrm{~m}$ to $1800 \mathrm{~m}$. Culex tigripes were only in the altitudinal class range between $1801 \mathrm{~m}$ and $2300 \mathrm{~m}$. It was also the least abundant in this altitudinal class range (Table 1). Further analysis showed that none of the Culex species significantly correlated with altitude ( $p>0.05$; Table 2$)$.

\section{Anopheles species}

The distribution of Anopheles species in the altitudinal class ranges were An. pharoensis (385.2), An. coustani (108.7), An. gambiae s.l (74.5) and An. funestus (18.0) 
between $800 \mathrm{~m}$ to $1300 \mathrm{~m}$; An. pharoensis (205.0), An. coustani (56.3) and An. gambiae s.l (39.3) between $1301 \mathrm{~m}$ to $1800 \mathrm{~m}$; An. pharoensis (44.3), An. gambiae s.l (15.0) and An. coustani (9.5) between $1801 \mathrm{~m}$ to $2300 \mathrm{~m}$ (Table 2).

An. pharoensis was the most abundant among Anopheles species in all altitudinal class ranges, with its population significantly correlated with altitude $(\mathrm{r}=-0.40$; $\mathrm{t}_{32}=-2.50 ; \mathrm{p}=0.02 ;$ Table 2). Compared to Culex and Anopheles species, it was the second most abundant species after $C x$. quinquefaciatus. An.funestus was only found in the $800 \mathrm{~m}$ to $1300 \mathrm{~m}$ altitudinal class range with the least abundance.

\section{Aedes species}

Aedes taylori was the only Aedes species present. Its distribution was not correlated with altitude $\left(\mathrm{r}=0.32 ; \mathrm{t}_{32}=\right.$ $1.91 ; p=0.07$; Table 2). It was found only in the $1801 \mathrm{~m}$ to $2300 \mathrm{~m}$ altitudinal class range, with a relative abundance of 43.3 .

\section{Effects of ecological factors on diversity and distribution of species}

Statistical analysis showed that some ecological parameters significantly affected distribution of mosquito species. Turbidity significantly affected the number of $C x$. tigripes (Turbid; $\beta=2.38 ; \mathrm{t}=2.256 ; \mathrm{p}=0.0343$ ). Habitat form significantly affected the number of $C x$. tigripes (spring bank; $\beta=3.951 ; \mathrm{t}=2.403 ; \mathrm{p}=0.0251$ ), $C x$. annulioris (Hoof print; $\beta=27.2 ; \mathrm{t}=-2.195 ; \mathrm{p}=0.039$ ) and An. pharoensis (Marsh; $\beta=33.235 ; \mathrm{t}=2.319 ; \mathrm{p}=0.0301$ ).

\section{Most preferred habitat for larvae}

Shannon-Weiner diversity index showed that a Riverbank, where turbidity was clear and both vegetation and other organisms were present, recorded the highest diversity of mosquito larvae species $\left(\mathrm{H}^{\prime}=1.721\right.$; Table 3$)$. Diversity in habitats showed correlation with altitude $(\mathrm{r}=$ $0.34, \mathrm{t}_{32}=-2.07, \mathrm{df}=32, \mathrm{p}=0.05$ : Table 2).

Table 1. Different mosquito species collected in different altitudinal class ranges

\begin{tabular}{|c|c|c|c|}
\hline \multirow[b]{2}{*}{ Species } & \multicolumn{3}{|c|}{ Total abundance } \\
\hline & $800-1300 \mathrm{~m}$ & $1301-1800 \mathrm{~m}$ & $1801-2300 \mathrm{~m}$ \\
\hline Culex pipiens & 206.3 & 91.9 & 175.0 \\
\hline Cx. quinquefaciatus & 886.6 & 409.0 & 1684.2 \\
\hline$C x$. annulioris & 76.0 & 126.5 & 130.0 \\
\hline$C x$. poicilipes & 18.8 & 126.3 & 105.9 \\
\hline$C x$. tigripes & 0.0 & 0.0 & 24.9 \\
\hline Anopheles pharoensis & 385.2 & 205.0 & 44.3 \\
\hline An. coustani & 108.7 & 56.3 & 9.5 \\
\hline An. gambiae & 74.5 & 39.3 & 15.0 \\
\hline An. funestus & 18.0 & 0.0 & 0.0 \\
\hline Aedes taylori & 0.0 & 0.0 & 43.3 \\
\hline Taxa & 8 & 7 & 9 \\
\hline Individuals & 1774.1 & 1054.3 & 2232.1 \\
\hline $\mathrm{D}$ & 0.318 & 0.2289 & 0.5821 \\
\hline $\mathrm{H}^{\prime}$ & 1.462 & 1.686 & 0.9836 \\
\hline $\mathrm{e}^{\wedge} \mathrm{H} / \mathrm{S}$ & 0.5395 & 0.7712 & 0.2971 \\
\hline
\end{tabular}

Note: *In columns are standardized numbers of mosquito larvae (Relative abundance)
Statistical analysis showed that only hoof print $(\beta=-$ $0.5168 ; \mathrm{t}=-2.617 ; \mathrm{p}=0.0157)$, Water pit $(B=-0.498 ; \mathrm{t}=-$ 2.345; $\mathrm{p}=0.0284)$ and presence of vegetation $(\beta=0.597 ; \mathrm{t}$ $=2.558 ; \mathrm{p}=0.018)$ significantly influenced diversity. Further analysis showed that a combination of vegetation and water quality had the greatest effect on diversity (AIC $=29.9$ ). The most preferred habitat for larval species was therefore dictated mainly by vegetation and the level of water quality.

Table 2. Correlation of the effect of altitude on the distribution of different mosquito species

\begin{tabular}{lcccc}
\hline \multirow{2}{*}{\multicolumn{1}{c}{ Species }} & \multicolumn{4}{c}{ Correlation to altitude } \\
\cline { 2 - 5 } & $\mathbf{r}$ & $\boldsymbol{T}$ & $\boldsymbol{D f}$ & $\boldsymbol{P}$ \\
\hline Aedes taylori & 0.32 & 1.91 & 32 & 0.07 \\
Anopheles coustani & -0.24 & -1.43 & 32 & 0.16 \\
An. fenestus & -0.16 & -0.92 & 32 & 0.37 \\
An. gambiae s.l & -0.18 & -1.01 & 32 & 0.32 \\
An. pharoensis & -0.40 & -2.50 & 32 & 0.02 \\
Culex annulioris & 0.05 & 0.31 & 32 & 0.76 \\
Cx. pipiens & 0.04 & 0.22 & 32 & 0.83 \\
Cx. poicilipes & 0.21 & 1.23 & 32 & 0.23 \\
Cx. quinquefaciatus & 0.26 & 1.49 & 32 & 0.14 \\
Cx. tigripes & 0.39 & 2.39 & 32 & 0.23 \\
Diversity in habitats & -0.34 & -2.07 & 32 & 0.05 \\
\hline
\end{tabular}

Table 3. Habitat species diversity

\begin{tabular}{|c|c|c|c|c|c|c|}
\hline Ititude & $\begin{array}{c}\begin{array}{c}\text { Habitat } \\
\text { form }\end{array} \\
\end{array}$ & $\begin{array}{l}\text { Water } \\
\text { quality }\end{array}$ & & $\begin{array}{c}\text { Other } \\
\text { organisms }\end{array}$ & $\begin{array}{c}\text { Number } \\
\text { sof species }\end{array}$ & $H^{I}$ \\
\hline 1334 & Riverbank & Clear & Present & Present & 7 & 1.721 \\
\hline 1457.79 & Dammargin & TTurbid & Present & Present & 5 & 1.467 \\
\hline 1450.17 & 7 Springbank & Clear & Present & Present & 5 & 1.466 \\
\hline 1019.81 & Marsh & Clear & Present & Present & 5 & 1.458 \\
\hline 1457.79 & Dammargin & Clear & Present & Present & 5 & 1.271 \\
\hline 1925 & Dammargin & AClear & Present & Present & 4 & 1.219 \\
\hline 1450.17 & Springbank & Clear & Present & Present & 4 & 1.203 \\
\hline 982.93 & Lakemargin & AClear & Present & Present & 4 & 1.193 \\
\hline 1323 & Riverbank & Clear & Present & Present & 5 & 1.123 \\
\hline 987.2 & Floodzone & Turbid & Present & Present & 3 & 1.048 \\
\hline 982.93 & Hoofprint & Clear & Present & Present & 3 & 0.9802 \\
\hline 1019.81 & Marsh & Turbid & Present & Present & 4 & 0.9764 \\
\hline 987.2 & Floodzone & Clear & Absent & Absent & 3 & 0.9743 \\
\hline 983.24 & Lakemargin & Clear & Present & Present & 3 & 0.9103 \\
\hline 2212 & Springbank & Clear & Present & Present & 6 & 0.8957 \\
\hline 1015.24 & Marsh & Clear & Present & Present & 5 & 0.8025 \\
\hline 983.24 & Lakemargin & aClear & Present & Present & 4 & 0.7834 \\
\hline 987.2 & Floodzone & Clear & Present & Present & 3 & 0.6883 \\
\hline 1457.79 & Dammargin & AClear & Absent & Absent & 2 & 0.6735 \\
\hline 987.2 & Floodzone & Turbid & Present & Present & 2 & 0.672 \\
\hline 2140 & Waterpit & Clear & Present & Present & 2 & 0.6555 \\
\hline 999.7 & Hoofprint & Clear & Present & Present & 2 & 0.6269 \\
\hline 999.7 & Hoofprint & Clear & Present & Absent & 2 & 0.6211 \\
\hline 2177 & Waterpan & Turbid & Present & Absent & 2 & 0.5196 \\
\hline 1837 & Dammargin & Clear & Present & Present & 2 & 0.518 \\
\hline 2177 & Waterpan & Turbid & Present & Absent & 3 & 0.4769 \\
\hline 2140 & Waterpit & Turbid & Present & Present & 4 & 0.4699 \\
\hline 999.7 & Hoofprint & Turbid & Present & Present & 2 & 0.3365 \\
\hline 2212 & Springbank & Turbid & Absent & Absent & 1 & 0 \\
\hline 2179 & Waterpit & Clear & Absent & Absent & 1 & 0 \\
\hline 2179 & Waterpit & Turbid & Absent & Absent & 1 & 0 \\
\hline 2179 & Waterpit & Turbid & Absent & Absent & 1 & 0 \\
\hline 999.7 & Hoofprint & Clear & Absent & Present & 1 & 0 \\
\hline 987.2 & Floodzone & Turbid & Absent & Absent & 1 & 0 \\
\hline
\end{tabular}




\section{Discussion}

The only Aedes species identified was Ae. taylori in the altitudinal range between $1801 \mathrm{~m}$ to $2300 \mathrm{~m}$. This species has been implicated as a vector of yellow fever in sylvatic transmission. Its ability to feed on monkeys and humans enables it to spread the yellow fever virus from monkeys to human beings (Digoutte 1999). Primary infections of RVF result from floodwater Aedes species, which are considered reservoir hosts of RVF virus due to trans-ovarian transmission and ability of the eggs to diapause in the soil for months or years until there is flooding (Sang et al. 2010). Flood water Aedes species in Kenya include Ae. mintoshi, Ae. ocharacieus, Ae. sudanensis, and Ae. circumluteolus (Lutomiah et al. 2013).

None of these species were identified in the entire study area within the study period. The results, therefore, indicate that there was no risk of RVF first outbreak based on the identified vectors in the study area during the study period. This was consistent with Baringo county vector-borne disease unit (VBDU) data and public health records. They indicated no cases of RVF were reported between January 2013 and September 2014 within the study region.

The RVF virus has previously been isolated in all the three genera identified in the study area (Sang et al., 2010). Many mosquitoes and sandflies are susceptible to RVF if they feed on an infected host and can cause secondary transmission of the virus. The wide range of such secondary vectors causes sudden epidemics of the virus after primary infection by the flood water Aedes species (Linthicum et al. 1985). This indicated that, although there were no primary vector larvae species identified in the study area, in case of entry of infected individuals such as cattle into the region, there would be a possible epidemic, especially if this was in the rainy season as mosquito species reach their peak abundances during such seasons (Uyi 2013).

Among the identified 10 species, five were Culex mosquito species; $C x$ quinquefaciatus, $C x$. pipiens, $C x$. annulioris, $C x$. poicilipes and $C x$. tigripes. Apart from being secondary vectors of RVF, anop species have been implicated as vectors of various other arbovirus diseases. An example of such a disease is the West Nile Virus. The West Nile Virus is transmitted by Culex species, from birds to humans and other mammals. This results from their ability to feed on mammals and birds (Molei et al., 2006). Evidence of the West Nile virus transmission in Kenya was found in mosquitoes collected in various parts, including the former Rift valley province of which Baringo, currently Baringo County, was part (LaBeaud et al. 2011). None of the Culex species showed a significant correlation to altitude. This implied that in case of emergence of RVF, West Nile Virus, or any other disease spread by the Culex species, whose distribution was not limited by altitude, the disease might spread rapidly in the entire county if rapid interventions are not initiated.

Culex quinquefaciatus was the most abundant species in the study area, and $C x$ tigripes were the least abundant. Culex quinquefaciatus, apart from being among secondary vectors of RVF in epidemics in Kenya (Sang et al. 2010), is also the primary vector of urban lymphatic filariasis, caused by the nematode Wuchereria bancrofti (Bockarie et al. 2009). However, there are no cases of vectortransmitted filariasis in Baringo County. Any examples that come in are from the coastal regions of Kenya. Mosquito species in the area cannot transmit the disease (unpublished data, Baringo County, VBDU). Culex tigripes is a predator of other mosquito larvae and can be used as larval biological control (Appawa et al., 2000). With the increase in highland malaria all over Kenya and considering it was in the high-altitude regions, it can be exploited as a measure of reducing highland malaria transmission.

Like $C x$. quinquefaciatus and $C x$. tigripes, the other three Culex species, Cx. pipiens, $C x$. annulioris and $C x$. poicilipes did not show any significant correlation with altitude. This indicates that any diseases they transmit can be spread both in the highlands and the lowlands, leading to infections in the entire region. Culex pipiens was implicated as the primary vector maintaining the RVF epidemic in Egypt from 1971 to 1978 (Hoogstraal et al., 1979). The laboratory test of $C x$. pipiens strains have also shown that apart from being susceptible to the RVF virus, they are also vulnerable to West Nile Virus (Amraoui et al., 2012). It is also a primary vector of the Ndumu Virus (NDUV), as reported in a study done in Garissa, Kenya, where evidence of trans-ovarian transmission of the virus was recorded (Lutomiah et al. 2014). Studies in Senegal indicated that $C x$. poicilipes was the primary RVF virus vector after the 1998 outbreak in Mauritania (Diallo et al. 2000). RVF viruses were isolated from $C x$. annulioris species in the 2007/2008 epidemic in Kenya (Sang et al. 2010). These are further indications that all the Culex species identified in the study area are secondary vectors of RVF. Therefore the fact that elevation does not limit them indicates that all regions of Baringo County have a potential risk of RVF secondary outbreaks.

Among the four Anopheles species identified in the study area, only An. pharoensis showed a significant correlation with altitude. However, between the altitudinal classes, the least abundances of Anopheles species were in the high-altitude class (1801-2300 m). Anopheles pharoensis was the most abundant Anopheles species and the second most abundant after $C x$. quinquefaciatus amongst all species identified in the study area. This is contrary to what a study in 2011 established, where a sibling species of An. gambiae s.l, and An. arabiensis was the most abundant (Mala et al. 2011). Anopheles pharoensis has been documented as an efficient malaria vector in Senegal (Carrara et al., 1990). It might also be an efficient vector in Baringo County, considering the many cases of malaria, which were higher during the study period (Unpublished data, Baringo county public health records). Studies on its biting habits in Kapkuikui village, Baringo County, indicated that it bites more often outdoor than indoors and is exophilic (Aniedu 1993). This might be the reason for its success since interventions in Baringo County mainly involve using insecticide-treated bed nets and pyrethrum spraying inside houses. These affect indoor bitters. Anopheles funestus and An. gambiae s.l are documented as endophilic and prefer biting indoors than 
outdoors (Aniedu 1993). This might explain their low larval abundances compared to An. pharoensis. Anopheles funestus larvae were the least abundant amongst Anopheles species. They were identified only in the low altitude region ( $800 \mathrm{~m}$ to $1300 \mathrm{~m}$ ). This is consistent with findings in a study done in 2011 within the low altitude region where it was the least abundant species (Mala et al. 2011). Anopheles coustani had a higher abundance than An. funestus and An. gambiae, but lower than An. pharoensis.

Individual species responded to different ecological parameters in the same habitat differently, while others were not affected by any of the recorded parameters. Results on Culex species are consistent with findings in a study carried out in villages within Mwea, Kenya, where Culex species responded differently to various ecological parameters in habitats (Muturi et al., 2007). In this study, only $C x$. annulioris and $C x$. tigripes responded to the recorded habitat parameters; hoof print habitat form for $C x$. annulioris, spring bank habitats form, and turbidity for $C x$. tigripes. Vegetation and turbidity in habitats had the most significant influence on diversity.

However, habitat diversity negatively correlated with altitude, indicating that habitat diversity reduced as height increased. None of the Culex species showed any significant interactions on the interaction between species in a habitat. However, there were significant interactions between An. funestus and An. coustani. Anopheles pharoensis showed substantial interactions with $A n$. coustani in the habitats.

In conclusion, the study hypothesis predicted that immature stages of malaria and RVF vector species vary amongst habitats along the altitudinal gradient. However, the results show only the distribution of An. pharoensis had a negative association with altitude. The implication is a need for continuous monitoring of vector species to avoid malaria and RVF outbreaks that would likely affect highlands and lowlands, assuming the vector competence of adult mosquitoes found in both regions is similar. During monitoring, habitats with clear water and vegetation would be the most probable culprit for larvae breeding.

\section{REFFERENCE}

Amraoui F, Krida G, Bouattour A, Rhim A, Daaboub J, Harrat Z, Failloux AB. 2012. Culex pipiens, an experimental efficient vector of West Nile and Rift Valley fever viruses in the Maghreb region. PloS One 7: e36757. DOI: 10.1371/journal.pone.0036757.

Aniedu I. 1997. Dynamics of malaria transmission near two permanent breeding sites in Baringo district, Kenya. Indian J Med Res 105: 206211.

Appawu MA, Dadzie SK, Quartey SQ. 2000. Studies on the feeding behaviour of larvae of the predaceous mosquito Culex (Lutzia) tigripes Grandpre and Chamoy (Diptera: Culicidae). Intl J Trop Insect Sci 20 (4): 245-250. DOI: 10.1017/S1742758400015599.

Bacaer N, Guernaoui S. 2006. The epidemic threshold of vector-borne diseases with seasonality. J Math Biol 53 (3): 421-436. DOI: 10.1007/s00285-006-0015-0.

Bockarie MJ, Pedersen EM, White GB, Michael E. 2009. Role of vector control in the global program to eliminate lymphatic filariasis. Ann Rev Entomol 54: 469-487. DOI 10.1146/annurev.ento.54.110807.090626.

Carrara GC, Petrarca V, Niang M, Coluzzi M. 1990. Anopheles pharoensis and transmission of Plasmodium falciparum in the
Senegal River delta, West Africa. Med Vet Entomol 4 (4): 421-424. DOI: $10.1111 /$ j.1365-2915.1990.tb00460.x.

Cox J. 1999. Mapping Malaria Risk in the Highlands of Africa. MARA/Durban. London School of Hygiene and Tropical Medicine, London, UK.

Diallo M, Lochouarn L, Ba K, Sall AA, Mondo M, Girault L, Mathiot C. 2000. First isolation of the Rift Valley fever virus from Culex poicilipes (Diptera: Culicidae) in nature. Am J Trop Med Hygiene 62 (6): 702-704. DOI: 10.4269/ajtmh.2000.62.702.

Digoutte JP. 1999. Present status of an arbovirus infection: yellow fever, its natural history of hemorrhagic fever, Rift Valley fever. Bulletin de la Societe de Pathologie Exotique 92 (5): 343-348.

El Vilaly AE, Arora M, Butterworth MK, Jarnagin W, Comrie AC. 2013. Climate, environment, and disease: The case of Rift Valley fever. $\begin{array}{lllll}\text { Progr Phys Geogr } 37 & \text { (2): 259-269. }\end{array}$ 10.1177/0309133313478315.

Gillies MT, de Meillon B. 1968. The Anophelinae of Africa, South of the Sahara. The South African Institute for Medical Research, Johannesburg

Githeko AK, Lindsay SW, Confalonieri UE, Patz JA. 2000. Climate Change and Vector-Borne Diseases: A Regional Analysis. Bulletin of World Health Organization 78 n.9 Genebra Jan.

Hoogstraal H, Meegan JM, Khalil GM, Adham FK. 1979. The Rift Valley fever epizootic in Egypt 1977-1978: 2. Ecological and entomological studies. Trans R Soc Trop Med Hygiene 73 (6): 624-629. DOI: 10.1016/0035-9203(79)90005-1.

Kenya Medical Research Institute. 2014. Kenya malaria fact sheet. Kenya medical research institute. http://www.kemri.org/index.php/helpdesk/search/diseases-a-conditions/29- malaria/113-Kenya-malariafact-sheet.

Kiritani K. 2006. Predicting impacts of global warming on population dynamics and distribution of arthropods in Japan. Popul Ecol 48 (1): 5-12. DOI: 10.1007/s10144-005-0225-0.

LaBeaud AD, Sutherland LJ, Muiruri S, Muchiri EM, Gray LR, Zimmerman PA, King CH. 2011. Arbovirus prevalence in mosquitoes, Kenya. Emerg Infect Dis 17 (2): 233-241. DOI: 10.3201/eid1702.091666.

Li Z, He Y, Winfred H, Wang X, Zhang W, Cao W, Du J, Xin H, Chang L. 2012. Altitude dependency of trends of daily climate extremes in southwestern China, 1961-2008. J Geograph Sci 22 (3): 416-430. DOI: $10.1007 / \mathrm{s} 11442-012-0936-\mathrm{z}$.

Linthicum KJ, Davies FG, Kairo A, Bailey CL. 1985. Rift Valley fever virus (family Bunyaviridae, genus Phlebovirus). Isolations from Diptera collected during an inter-epizootic period in Kenya. J Hygiene 95 (1): 197-209. DOI: 10.1017/S0022172400062434.

Lutomiah J, Bast J, Clark J, Richardson J, Yalwala S, Oullo D, Sang R. 2013. Abundance, diversity, and distribution of mosquito vectors in selected ecological regions of Kenya: public health implications. J Vector Ecol 38 (1): 134-142. DOI: 10.1111/j.19487134.2013.12019.x.

Lutomiah J, Ongus J, Linthicum KJ, Sang R. 2014. Natural vertical transmission of Ndumu Virus in Culex pipiens (Diptera: Culicidae) mosquitoes collected as larvae. J Med Entomol 51 (5): 1091-1095. DOI: 10.1603/ME14064

Mala AO, Irungu LW, Shililu JI, Muturi EJ, Mbogo CC, Njagi JK, Githure JI. 2011. Dry season ecology of Anopheles gambiae complex mosquitoes at larval habitats in two traditionally semi-arid villages in Baringo, Kenya. Parasit Vect 4 (1): 1-11. DOI: 10.1186/1756-3305-425.

Molaei G, Andreadis TG, Armstrong PM, Anderson JF, Vossbrinck CR. 2006. Host feeding patterns of Culex mosquitoes and West Nile virus transmission, northeastern United States. Emerg Infect Dis 12 (3): 468474. DOI: 10.3201/eid1203.051004.

Muturi EJ, Shililu JI, Gu W, Jacob BG, Githure JI, Novak RJ. 2007. Larval habitat dynamics and diversity of Culex mosquitoes in rice agro-ecosystem in Mwea, Kenya. Am J Trop Med Hyg 76: 95-102. DOI: 10.4269/ajtmh.2007.76.95.

Norris DE. 2004. Mosquito-borne diseases as a consequence of land-use change. EcoHealth 1 (1): 19-24. DOI: 10.1007/s10393-004-0008-7.

Sang R, Kioko E, Lutomiah J, Warigia M, Ochieng C, O’Guinn M, Richardson J. 2010. Rift Valley Fever Virus epidemic in Kenya, 2006/2007: the entomologic investigations. Am J Trop Med Hyg 83 (2): 28-37. DOI: 10.4269/ajtmh.2010.09-0319.

Swanepoel R, Paweska JT. 2011. Rift Valley Fever. Oxford Textbook of Zoonoses: Biology, Clinical Practice, and Public Health. Oxford 
University Press, London, UK. DOI: 10.1093/med/9780198570028.003.0043.

Tsuda Y, Komagata O, Kasai S, Hayashi T, Nihei N, Saito K, Kobayashi M. 2008. A mark-release-recapture study on dispersal and flight distance of Culex pipiens pallens in an urban area of Japan. J Am Mosq Control Assoc 24 (3): 339-343. DOI: 10.2987/5754.1.

Uyi COO. 2013. Temporal distribution of and habitat diversification by some mosquitoes (Diptera: Culiciclae) species in Benin City, Nigeria. J Entomol 10 (1): 13-23. DOI: 10.3923/je.2013.13.23.

Verdonschot PF, Besse-Lototskaya AA. 2014. Flight distance of mosquitoes (Culicidae): A metadata analysis to support the management of barrier zones around rewetted and newly constructed wetlands. Limnol Ecol Manag Inland Waters 45: 69-79. DOI: 10.1016/j.limno.2013.11.002.

Wettstein W, Schmid B. 1999. Conservation of arthropod diversity in montane wetland; effects of altitude, habitat quality and habitat fragmentation on butterflies and grasshoppers. J Appl Ecol 36 (3): 363-373. DOI: 10.1046/j.1365-2664.1999.00404.x.

Woods CW, Karpati AM, Grein T, McCarthy N, Gaturuku P, Muchiri E, World Health Organization Hemorrhagic Fever Task Force. 2002. An outbreak of Rift Valley fever in northeastern Kenya. 1997-98. Emerg Infect Dis 8 (2): 138-144. DOI: 10.3201/eid0802.010023.

World Health Organization. 1975. Manual on practical entomology in malaria. WHO, Geneva.

World Health Organization. 2007. Rift Valley Fever in Kenya, Somalia, and the United Republic of Tanzania. World Health Organization Global alert and response. WHO, Geneva

World Health Organization. 2013a. Malaria entomology and vector control. World Health Organization, Geneva.

World Health Organization. 2013b. Malaria report. World Health Organization, Geneva. 